\title{
Foreign Direct Investments and Labour Force Indicators in Transition Economies: Linear Mixed-Effects Models Impact Analysis
}

\author{
Milica Peric ${ }^{1}$ - Sanja Filipovic ${ }^{2}$ \\ Faculty of Business, Singidunum University, Belgrade \\ Faculty of Business, Singidunum University and Institute of Social Sciences, \\ Belgrade
}

\begin{abstract}
Foreign Direct Investments and Labour Force Indicators in Transition Economies: Linear Mixed-Effects Models Impact Analysis. Main objective of this paper is to analyse the impact of foreign direct investments (FDI) on labour force in transition economies, through monitoring and quantification of selected labour force market indicators. This research analyses and discusses the effects of FDI inward flow on labour force indicators in transition economies from the economic and social point of view (i.e. quality of life of labour force). The paper argues that FDI inward flow should have a positive effect on labour force, through the increase of employment growth rate, wages, and reduction of income inequality. Data processing was done by applying Linear Mixed-Effects Models on 17 transition countries during the period $2000-2017$. The findings show a positive and significant impact of FDI inward flow on employment rate and on wages and salaries, while the impact of FDI inward flow on income inequality is uncertain. Finally, there are policy and future research recommendations.

Sociológia 2021, Vol. 53 (No. 3: 238-265)

https://doi.org/10.31577/sociologia.2021.53.3.9
\end{abstract}

Key words: Foreign direct investments; transition economies; employment; wages; income inequality

Subject classification codes: C12, E20, F21, F23, O40.

\section{Introduction}

International movement of foreign capital is defined as a movement of capital from a country where capital is abundant to a country in need of capital. According to Dogru (2012), the reasons why developing countries attract foreign direct investments (FDI) are a lack of capital to finance domestic economic activities, a lack of technology and knowledge to launch domestic projects.

FDI is considered to be the most important element of globalization and liberalization of the global market. Consequently, a home-country entity can gain control through ownership of an overseas entity and affect the dynamism of the economy while placing a long-term capital. By acquiring a certain

\footnotetext{
1 Address: PhD student Milica Peric, Singidunum University, Faculty of Business, Danijelova 32, 11000 Belgrade, Serbia. E-mail: milicamip@gmail.com

2 Address: Prof. Dr. Sanja Filipovic, Singidunum University, Faculty of Business, Danijelova 32, 11000 Belgrade and Institute of Social Sciences, Kraljice Natalije 45, 11000 Belgrade. E-mail: sfilipovic@singidunum.ac.rs and sfilipovic@idn.org.rs
} 
degree of ownership in the country, the investor aims to connect related companies, accelerate the distribution of goods and services, and increase the efficiency of production and sales. Moreover, FDI foster labour market integration through the import of technology and best management practices (Hedvicakova et al. 2018; Beechler - Woodward 2009).

Three decades ago, after the fall of socialist and communist regimes, the transition in the Central Eastern European countries began (Myck - Oczkowska 2018). The transition in these countries comprehends economic transition through privatization (Filipovic - Miljkovic 2014; Vuksic 2016), gross domestic product (GDP) and employment formation and other macroeconomic indicators, which depend mostly of public sector and institutions (Grotkowska et al. 2018; Delibasic 2019; Filipovic - Miljkovic 2010). Brada et al. (2006) stress that conflicts and political instability reduces FDI inflow in transition countries, while the delayed transition along with conflicts have reduced FDI inflows in the Balkans.

In the globalized world, relations between economies are constantly intensifying (Filipovic - Miljkovic 2014). Furthermore, the relation between FDI and labour force is the actual phenomena in the world, particularly significant for the countries in transition (Stanisic 2008). Therefore, valuing the effects of the foreign capital on the host labour market will help understand the economic implications in the transition economies (Derado 2013; Taylor Driffield 2005).

The research is not about to develop the already recognizable FDI spillover effects, such as technology, education and skills, and productivity growth (Demena - Murshed 2018; Li - Luo 2019; Chiu - Lee 2019; Peric - Filipovic 2018; Lu et al. 2017; Iwasaki - Tokunaga 2016; Krammer 2010; Alili 2014). Instead, this research focuses on the impact of FDI inward flow on employment rate and paid wages and salaries in transition economies.

Indeed, one of the most relevant detected dilemma in transition economies is the income inequality (Le et al. 2019; Booth 2019; Shahbaz et al. 2017). This research further attempts to measure the impact of FDI inward flow on the income inequality coefficient. The reason for the above lies in the assumption that foreign companies bring along the transfer of new technology, skills and abilities (Melnyk et al. 2014; Kurtishi 2013; Buckley et al. 2002; Lin 2018), and consequently a decrease in income inequality (Tausch - Heshmati, 2012).

Therefore, the motives for measuring the impact of FDI inward flow on workers' indicators are several. Transition economies are highly dependent on FDI inward flow (Zugic 2010; Bartlett 2007; Alili - Adnett 2018). High dependency on FDI inward flow when it comes to labour force is reflected on both economic and social aspects of life. When labour force is engaged in economic and social changes, the quality of labour force is impacted and 
inevitably changes in time. The authors' assumption is the positive impact of FDI on the national economy, while seeking to fill the gap in the literature regarding the impact of FDI inward flow on the transition economies' labour force. Considering that economic/financial and social conditions (including the quality of life of labour force) are interconnected and that their connection is inevitable, this paper analysis is about to underline the significance of the FDI inward flow impact on labour force and its quality of life. The reason for choosing this particular country sample is, in the first place, transition country group dependency on FDI (Peric 2020). Secondly, the UNCTAD methodology for country classification is peculiar. Although UNCTAD relies on M49 classification (UNCTAD 2018b), the particular circumstances (e.g. postsocialism effects, transition to a market economy, the geographic locations, democracy implications) were taken into account for the definition group of transition economies (UNCTAD 2018c). Instead of other different classifications based explicitly on gross national income (GNI) or income level of the country, the authors rely on the above classification for this research. As for empirical evidence, the most critical effect of the FDI inward flow so far occurs in transition economies (Stanisic 2008; Alili - Adnett 2018).

As for the authors' knowledge, there has been no empirical research on the field of the impact of FDI inward flow on labour force quality of life through three labour force indicators in all 17 transition economies for the abovementioned period. This research is about to cover this gap in the literature.

The aim of this paper is to measure the impact of FDI inward flow on workers' indicators (employment rate, paid wages and salaries, and income inequality) in transition economies in the period $2000-2017$, with reference to both economic and social impact as a consequence of foreign capital import. It is known that FDI inward flow brings new technology and the creation of human capital in the host country, but its indirect impact on workers' indicators (for example, the creation of income inequality gap) deserves further analysis.

The findings of this research suggest the positive impact of FDI inward flow on employment rate and paid wages and salaries in transition countries, while the impact of FDI inward flow on income inequality is uncertain. This research serves researchers and public policy decision-makers in terms of improving laws and corporate rules, as well as corporate practices aimed at increasing paid wages and decreasing overall income inequality.

The structure of the rest of the paper is the following. The Section 2 presents the relevant literature review related to FDI and labour. Data sample is presented in the Section 3, while the econometrical choices are subject of the Section 4. The Section 5 shows the estimation of results, their interpretation and discussion along with the empirical load of evidence regarding the impact 
of FDI on the worker's indicators. The last, Section 6, presents conclusions and recommendations for public policy decision-makers and researchers for the future research.

\section{Review of the FDI impact on labour force}

Despite the theoretical FDI inflow importance (along with the physical and human capital accumulation, and international trade integration) for the increase in productivity, different studies show the opposite results. In Croatian manufacturing industry (over 23 sectors), the FDI inflow (both greenfield and brownfield) did not contribute to the higher labour productivity growth over the 1998 - 2007 period (Vuksic 2016). Sauvant (2005) presented the analysis of up-side down benefits from FDI, claiming that outward FDI was seen as a substitute for domestic investment in Brazil, Russia, India, China and South Africa (BRICS). In this way, domestic firms learn from abroad how to benefit domestic enterprises, such as to increase competitiveness and contribute to employees.

\section{FDI impact on employment}

Although different authors claim that FDI decreases unemployment rate in transition countries (Estrin 2017; Hubner 2011; Lee et al. 2011; Xu 2000), there is a number of authors who showed the absence of positive impact of FDI on unemployment in the countries covered by the study (Peric 2019; Grahovac - Softic 2017; Zdravkovic - Martinovic 2016; Sabic et al. 2012; Lee et al. 2009).

Estimating the impact of FDI inflow on employment in the Visegrad group of countries (Czech Republic, Hungary, Poland and Slovakia) in period 1993 2012, using the panel regression and Okun's law, Brincikova and Darmo (2014) found the positive impact in case of greenfield investment, and the negative impact in case of privatization $(M \& A)$, yet with no statistical significance. The Visegrad group of countries are market economies since 1989, and all of them joined the EU in 2004 and transited to the high income countries. In the time period covered by the Brincikova and Darmo's study (2014), the Visegrad group of countries were no longer communist, yet in transition since the EU accession.

While examining the impact of FDI inflow on average wage and employment in Serbia in the period 2005 - 2017, Peric (2019) found no statistically significant effect of FDI inflow on average wage and employment in this country. Using the sample of transition economies classified by UN, and applying panel regression estimation, Zdravkovic and Martinovic (2016) found that FDI effect on unemployment is insignificant in European transition countries. Similarly, Grahovac and Softic (2017) found almost the same results 
applying the same methodology for West Balkan countries: FDI inflow has no significant effect on unemployment. Although using different methodology, the correlation analysis, Sabic et al. (2012) found that FDI inflow had no significant effect on unemployment in Serbia.

Examining the impact of FDI on economic growth in Kazakhstan, the results of Lee et al. (2009) shown that FDI do not directly affect economic growth, as well as that employment (as the chosen indicator of growth) is not significantly affected by FDI inflow

As a resource-rich country, especially in oil, Azerbaijan is one of the largest importers of FDI in the South Caucasus Region. According to Hubner (2011), FDI in Azerbaijan brings a transfer of international know-how, management and technology, contributing to employment by only $1 \%$ in oil industry. Considering the large impact of oil industry on the country's GDP, it can be concluded that FDI inflow contributes to some extent to employment increase.

Furthermore, in transition economies FDI inflow increases unemployment in the initial phase, while later FDI inflow positively impact the unemployment rate decrease (Estrin 2017: 5). This phenomenon occurs for FDI inflow being mostly engaged in privatization of state-owned companies. In the initial phase, it requires the systematization of labour force, which affects downsizing of employment and later hiring of competitive workers with required skills and knowledge.

However a country is classified as transitional, developing or developed, the more a country is open, the greater the FDI positive impact on employment (Shengelia et al. 2020).

\section{FDI impact on wages}

Empirical studies testify to differences in outcomes regarding the impact of FDI on wages.

As for Hale and Xu (2016), Kurtovic et al. (2015), Bhandari (2007), FDI inflow contributes to the increase in wages. However, Estrin and Uvalic (2014) found that FDI is not directly correlated to wage increase. For the average wage in Serbia, the results obtained by Peric (2019) indicate no statistical significance, yet a tiny positive impact of FDI inflow in the year of the inflow in the country.

Bhandari (2007) applied OLS regression in order to estimate the impact of FDI on wage in transition countries, founding that FDI have a positive effect on average wages in these countries. Using the same methodology, Kurtovic et al. (2015) suggest a positive impact of FDI inflow on average net wages in Bosnia and Herzegovina, Montenegro, Macedonia and Serbia. Employing OLS regression, as well, there is evidence that FDI inflow has a positive impact on 
average net wage in Serbia only in the second year of FDI inflow performance (Peric 2019).

Hale and Xu (2016) conducted a meta-analysis of the literature with the aim to find similarities and differences in empirical findings. These authors found solid matches in outcomes, i.e. developing countries benefit from FDI in terms of higher wages, positive productivity spillovers, and increase in skill premium.

Estrin and Uvalic (2014) found that FDI generated no considerable impact on wages in transition economies. Popovic and Eric (2018) stressed that there is no significant impact of European Union FDI inflow on unit labour costs in Western Balkan transition economies. Instead, Bevan and Estrin (2000) assured that there was a significant negative correlation between FDI and unit labour costs.

In the CEECs (the Visegrad group of countries and Slovenia), Onaran and Stockhammer (2006) found disappointing but some positive results in the period 2000 - 2004. On one hand, FDI shown positive effects on wages, but only in the capital and skill intensive sectors. On the other hand, it was found that transition process, along with the FDI, contributed to higher productivity and more significant and positive effect on employment. As a consequence of the fall in unemployment, the wages shown overall flexibility. Contrary to FDI, long-term net effect of exports and imports proved to be negative and damaging to CEECs labour markets. Onaran and Stockhammer (2006) indicate the overall FDI negative effects on unskilled, but positive effects on skilled wages.

In order to estimate the relationship between FDI inflow and labour costs in transition economies, referring to the Central and Eastern European (CEE) economies and the economies of the Commonwealth of Independent States (CIS), Johnson (2006) used annual wage in manufacturing (as share of GDP per capita). Followed by regression analysis, Johnson found that wage is an important element for determining labour costs, which are crucial for the volume of efficiency-seeking FDI in the transition host country. Therefore, wage made a significant negative impact on FDI inflow for total transition economies, as well as for CIS countries, but insignificant impact for solely CEE sample.

Large foreign enterprises in Central and Eastern European economies are likely to pay higher wages compared to domestic firms, but only for limited period of time. In order to keep paying higher salaries, a foreign company aims at investing in education level (Shengelia et al. 2020). Some authors claim that foreign companies pay higher wages than the domestic companies, both public and private ones (Alili 2014), which is the strongest reason for growing inequality within a country. 


\section{FDI impact on inequality}

Hardy et al. (2018) explain the differences and similarities in the evolution of the job-content in post-transition and developed European economies, as well as how structural changes are responsible for both the differences and similarities. For the period 1998 - 2015, these authors claim that the Central and Eastern European countries are similar to EU14 in the non-routine cognitive tasks growth, and in decrease in manual jobs. The non-routine cognitive tasks growth is attributed to the technological innovations by causing educational effects as part of the structural changes.

When it comes to education, in both private and public sector, there is an increasing trend in the transition economies. Employees, even if being engaged in some specific field for years or decades, tend towards additional education (seminars, schools, lectures organized by the employers, but also driven by own decisions). In this way, employee's job perspectives appear to extend. In Poland, for example, there is a greater probability for female employment, especially in the public sector, which already shows over-employment as a consequence of former regimes institutional rules. This phenomenon affects higher brain drain and destruction of human capital quality (Grotkowska et al. 2018). According to these authors, the public sector preferences may cause poor career perspectives, emigration, and difficulties in retaining skilled labour force. Besides, there is empirical evidence that social well-being is highly determined by personal perception of institutional environment (Mrva 2020).

Alili and Adnett (2018) stress that the last twenty years have been characterised by the rise in globalisation that provoked a growth in income and wage inequality in European transition countries. Applying a cross-country empirical investigation, these authors attempted to estimate whether FDI affect wage inequality in transition economies. The findings show that a rising share of inward FDI in GDP increased wage inequality in transition countries, although its effect is relatively small. However, in the long run, the concave relationship between FDI and wage inequality is uncertain, supposing that the relatively low levels of FDI in many of the selected transition countries may be the consequence of uncertainty. In the period 1995 - 2006, Gini coefficient for Azerbaijan, Russia and Kyrgyzstan showed the highest levels of inequality (above 0.5). The lowest levels of inequality were recorded in the Czech Republic (0.26), Macedonia (0.28), Poland (0.30), Serbia (0.32) and Romania (0.35). These result indicate the diversity of single economies, as well as the impact of FDI inward flow on different labour market indicators.

Instead of assuming uncertain effects regarding the relation between FDI and Gini coefficient, Mah (2012) offers certainty in his work. Despite the importance of FDI inflow for the Korean economy that contributed to the higher flexibility in the labour market in the past few decades, during the 
period $1982-2008$ the income inequality in Korea deteriorated. The increase in FDI inflow is the direct consequence of the rise in Gini coefficient in Korea (Mah 2012), confirming the hypotheses and warnings of Feenstra and Hanson in the late nineties (Feenstra - Hanson 1997).

FDI effects on wage inequality and income distribution are related to skill abundance in the host economy. The estimates of Bruno et al. (2012) show significant heterogeneity in the FDI effect on skilled labour across Eastern Europe economies. Accordingly, the impact of inward FDI is significantly positive for Hungary, weakly negative for Poland, and negligible for the Czech Republic in the period $1994-2002$.

Estimating the impact of sectoral FDI on within-country income inequality in 60 developing middle-income countries for the period 1989 - 2010, using the error correction models, Bogliaccini and Egan (2017) found that the service sector is the most relevant factor. Considering the service sector needs for high skilled labour, these authors claim that FDI in service sector controls employment more than in the other sectors. Consequently, the service sector showed the most skill and wage biases in developing countries. As many scholars, Bogliaccini and Egan (2017) suggest that the governments should be careful with FDI attraction and dominant forms of existing structure of inward FDI.

The authors assume the general hypotheses: changes in FDI inward flow produce positive changes in employment rate and in paid wages and salaries, and negative effects in income inequality. Assumptions of positive impact on the employment rate and paid wages and salaries is justified by the general role of FDI: increase in employment, wages and salaries, and in economic growth and prosperity. Therefore, this positive assumption should be a logical lead to positive impact on quality of life of labour force. Assumption of negative effects on income inequality derives from the majority of scientific research results and common sense. For example, the greater the import of new technology, the lesser is the number of employees in the company (the advanced technology substitutes a number of employees). Moreover, foreign companies pay greater salary than the transition economy national average. Both factors affect the increase of inequality, and therefore the impact is expected to be negative.

\section{Data collection and setting}

Once the authors find literature that satisfies the needs of the research question, it is followed by the data collection and description of variables.

The data sample is for 17 transition economies according to the UNCTAD classification (UNCTAD 2018a), and the international statistical bases used for data collection are shown in the Table 1. 
Table 1: Data set and sources of each indicator

\begin{tabular}{llll}
\hline Variables & $\begin{array}{l}\text { Institutional indicator label } \\
\text { Foreign direct investment inward } \\
\text { flows }\end{array}$ & $\begin{array}{l}\text { Unit of measure } \\
\text { US dollars at current } \\
\text { prices in millions }\end{array}$ & Source \\
Employment rate & $\begin{array}{l}\text { Employment to population ratio, } \\
15+(\%) \text { (modelled ILO estimate) }\end{array}$ & in percentages & World Bank (2019a) \\
& $\begin{array}{l}\text { Wage and salaried workers, total } \\
(\% \text { of total employment) } \\
\text { (modelled ILO estimate) }\end{array}$ & in percentages & World Bank (2019b) \\
Wage & Gini index (World Bank estimate) & $\begin{array}{l}\text { equality; } 100 \text {-perfect } \\
\text { inequality) }\end{array}$ & World Bank (2019c) \\
Income inequality & & & \\
\hline
\end{tabular}

Note: World Bank is UNCTAD's partner. UNCTAD relies on World Bank for many indicators information (e.g. UNCTAD, 2016). The time series of data for employment and wages in the original UNSTAT database are short (see Bulletin of Statistics Online).

Source: See note

Description of variables is summarized in Table 2. Official definitions have been used for the variables, according to the agreed source.

\section{Table 2: Description of variables}

\begin{tabular}{|c|c|c|c|c|}
\hline & FDI inward flow & Employment rate & Wages & Income inequality \\
\hline 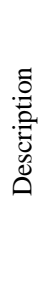 & $\begin{array}{l}\text { Capital provided } \\
\text { (either directly or through other } \\
\text { related enterprises) } \\
\text { by a foreign direct investor to an } \\
\text { enterprise, or capital } \\
\text { received from an investing } \\
\text { enterprise by a foreign } \\
\text { direct investor (UNCTAD, } \\
\text { 2019a) }\end{array}$ & $\begin{array}{l}\text { Proportion of } \\
\text { population (age } 15 \\
\text { and older) that is } \\
\text { employed in a } \\
\text { country. }\end{array}$ & $\begin{array}{l}\text { Workers and self- } \\
\text { employed workers } \\
\text { who receive wages } \\
\text { and salaries, i.e. } \\
\text { who hold the paid } \\
\text { employment jobs. }\end{array}$ & $\begin{array}{l}\text { Distribution in income } \\
\text { among individuals and } \\
\text { households. Gini index is } \\
\text { a measure of the degree of } \\
\text { inequality. }\end{array}$ \\
\hline 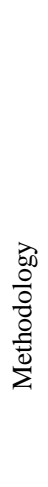 & $\begin{array}{l}\text { National institution reporting FDI } \\
\text { for individual country. Note: Data } \\
\text { and methodology for FDI are } \\
\text { provided in the annual } \\
\text { Methodological Note that } \\
\text { accompanies the World } \\
\text { Investment Report (UNCTAD, } \\
\text { 2019b). }\end{array}$ & $\begin{array}{l}\text { The estimates are } \\
\text { based mainly on } \\
\text { nationally } \\
\text { representative labour } \\
\text { force surveys. Other } \\
\text { sources (population } \\
\text { censuses and } \\
\text { nationally reported } \\
\text { estimates) are used } \\
\text { only when no survey } \\
\text { data are available in } \\
\text { the original country. }\end{array}$ & $\begin{array}{l}\text { The estimates are } \\
\text { based mainly on } \\
\text { nationally } \\
\text { representative } \\
\text { labour force } \\
\text { surveys. Other } \\
\text { sources } \\
\text { (population } \\
\text { censuses and } \\
\text { nationally reported } \\
\text { estimates) are used } \\
\text { only when no } \\
\text { survey data are } \\
\text { available in the } \\
\text { original country. }\end{array}$ & $\begin{array}{l}\text { Data on the distribution of } \\
\text { income is retrieved from } \\
\text { nationally representative } \\
\text { household } \\
\text { surveys. Depending on } \\
\text { availability of original } \\
\text { data, the distribution data } \\
\text { have been adjusted for } \\
\text { household size, providing } \\
\text { a more consistent measure } \\
\text { of per capita income or } \\
\text { consumption. }\end{array}$ \\
\hline
\end{tabular}

Source: Authors' presentation based on UNCTAD (2019a, b) and World Bank (2019a, b, c) 
The summary of the main macroeconomic indicators in the transition countries sample is presented for better comprehension and interpretation of the outcomes that follow both the logic and theory. Figures 1 and 2 are provided according to the single country profiles created by the UNCTAD data centre (UNCTAD 2020) and the World Bank data (2019a, 2019b, 2019c).

Figure 1: Foreign direct investment inward flow: 2000 - 2018 (in millions of dollars)

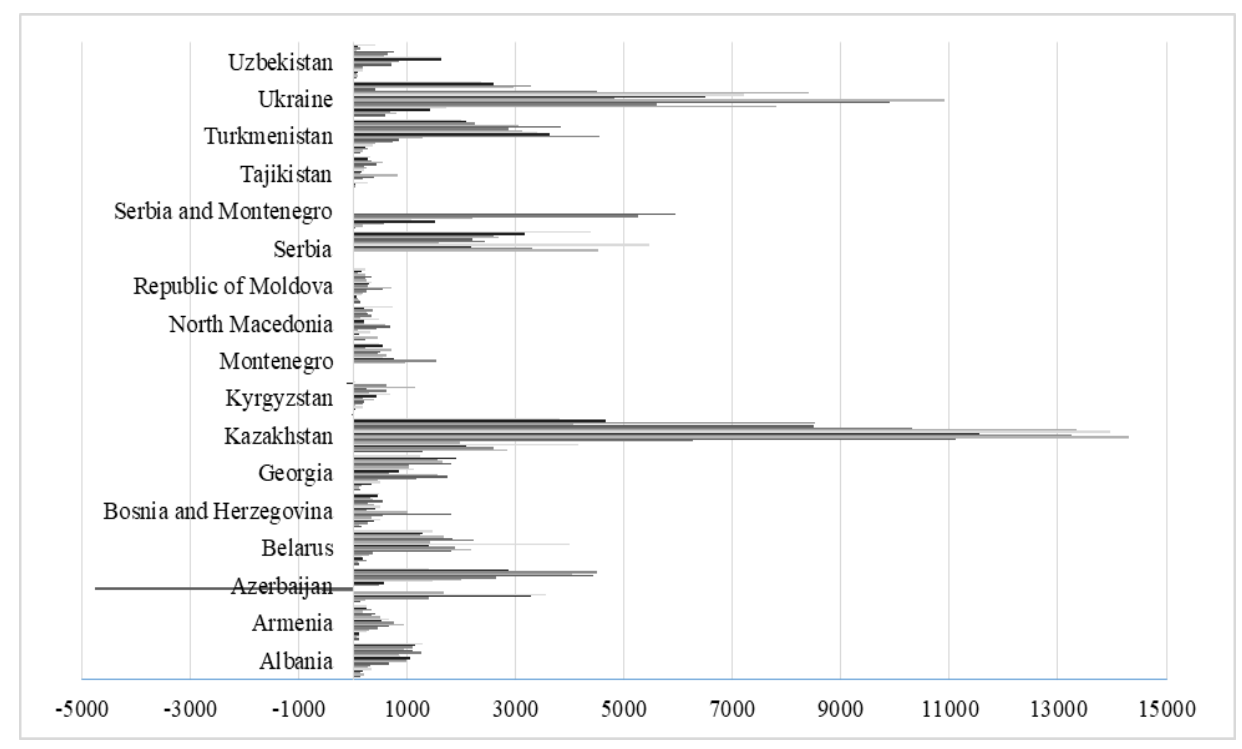

Note: Russia is excluded from the graph because of the extremely high values compared to the other countries in the sample.

Source: Authors' presentation based on the UNCTAD (2019c) data

In terms of FDI inward flow, Russia, Kazakhstan and Ukraine received the largest amount in the period $2000-2018$. The prevalent reason for the above is the natural resources availability in these countries. The smallest amount was most usually hosted in the smallest transition countries, such as Armenia, Moldova, Tajikistan, and the Western Balkan countries such as Bosnia and Herzegovina, and Macedonia in the same period.

A grate number of transition countries has experienced a falling trend in employment rate during the last 18 years (Azerbaijan, Belarus, Kazakhstan, Russia, Tajikistan, Turkmenistan, and Uzbekistan) with tiny variations in increase. The decline in employment is caused by privatization process, substitution of employees with machines and computers, but also by migration and decrease in population, called the brain drain phenomenon. The transition 
countries that experienced the increasing trend in employment during the period 2000 - 2018 are Albania, Moldova, Serbia, and recently Macedonia.

\section{Figure 2: Employment rate: 2000 - 2018}

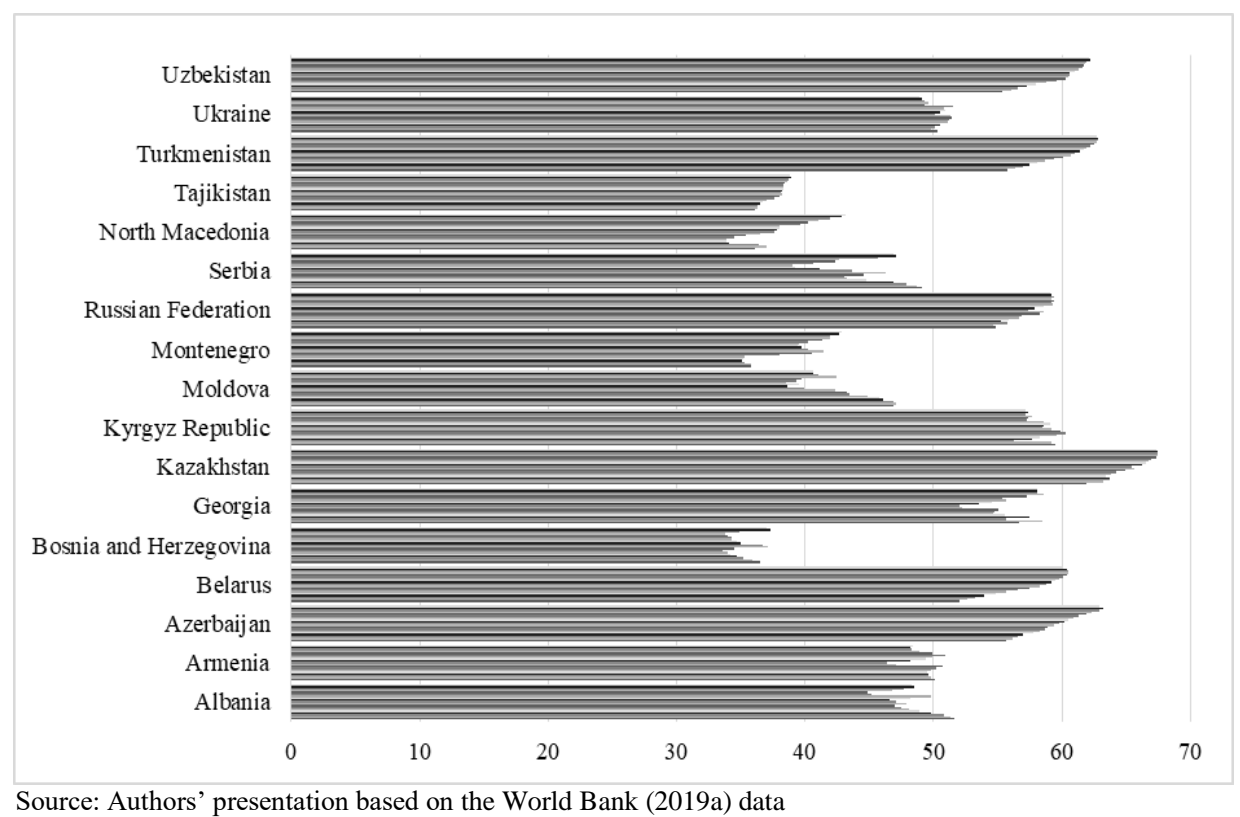

Source: Authors' presentation based on the World Bank (2019a) data

Figure 3a: Gini index: 2000 - 2018

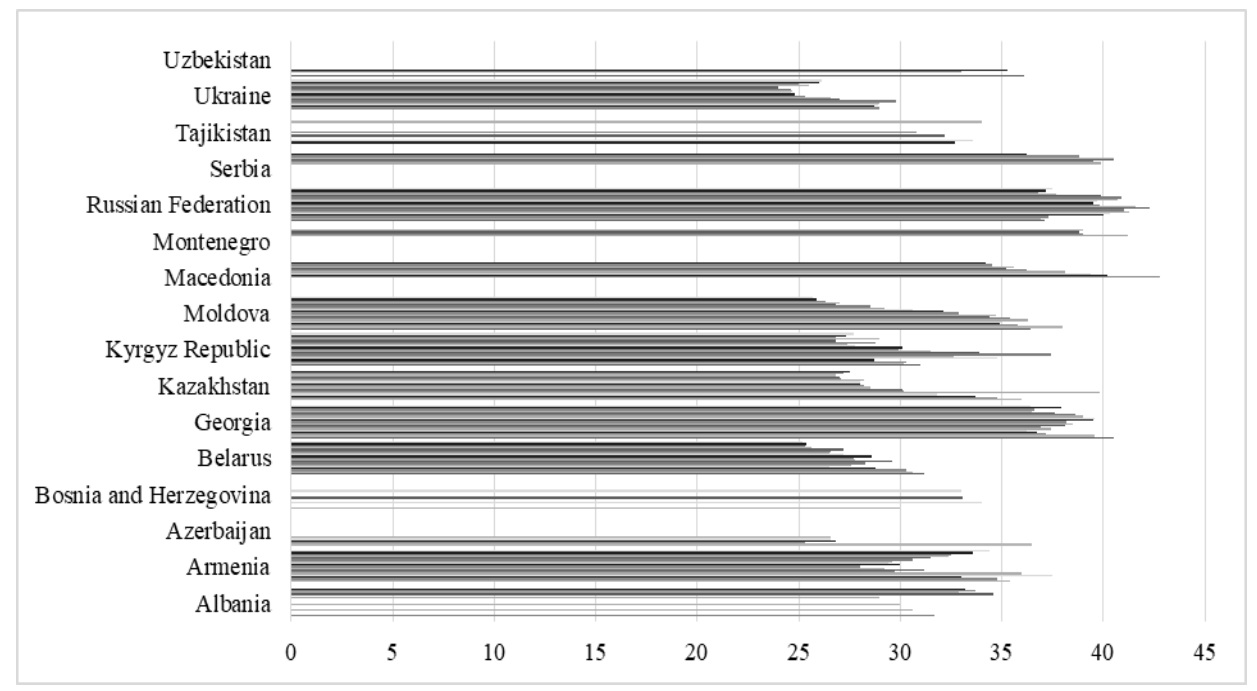

Note: There is no data on Gini index available for Turkmenistan Source: Authors' presentation based on the World Bank (2019c) data 
Figure $3 \mathrm{a}$ and $3 \mathrm{~b}$ show the unavailability of full time series for the recognized and most used index of income inequality. However, it is possible to extract general considerations. During the last 18 years and among the countries in economic transition, the greatest level of inequality has been registered in Macedonia, Montenegro, Russia, and Serbia, going beyond 40\%. A few countries remained under $26 \%$ at some point: Azerbaijan, Belarus, Moldova, and Ukraine.

Figure 3b: Gini index: 2000 - 2018: Descriptive statistics

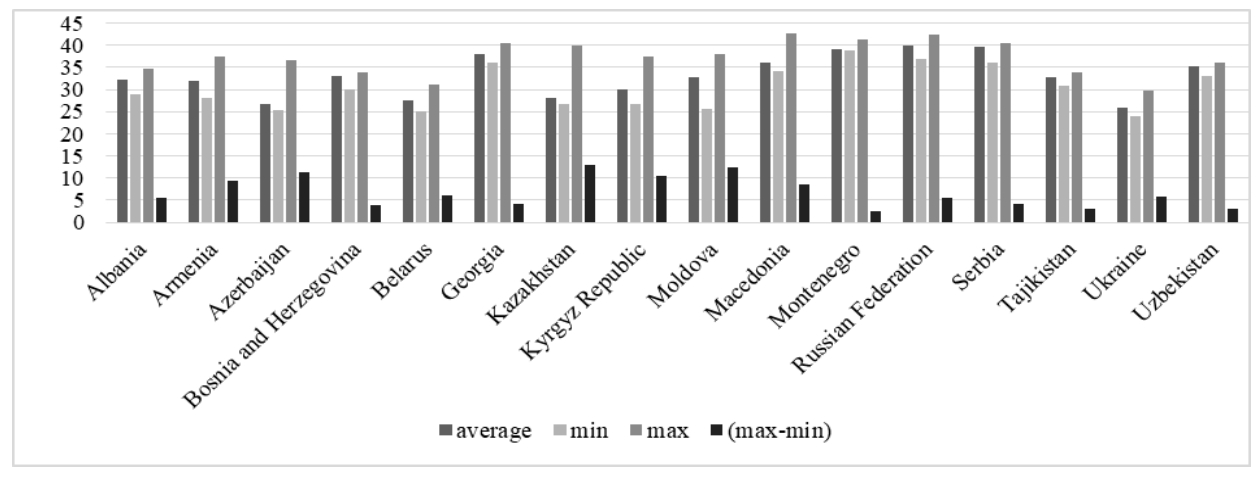

Source: Authors' calculation

Azerbaijan had the level of the Gini index of $36.5 \%$ in 2001, achieving $11.2 \%$ of negative difference after one sole year, $25.3 \%$ in 2002 . Other countries in the sample with the variation of Gini above $10 \%$ are Kazakhstan that slipped from 39 (2005) to $26.8 \%$ (2015) with total of $13 \%$ of decrease in Gini index, Kyrgyzstan went from 37.4 (2006) to $26.8 \%$ (2016) with the total improvement in Gini of $10.6 \%$, and Moldova that decreased in Gini for $12.3 \%$ from 38 (2001) to $25.7 \%$ (2018). The average Gini for the countries in the sample is $32.8 \%$ in the period $2000-2018$. According to the general trend based on available data, it seems that income inequality is decreasing in the former Soviet countries in Asia. In the Western Balkan countries, the average Gini is $36.05 \%$ in the same period. The greatest income inequality, above $40 \%$, is registered in Macedonia, Montenegro, and Serbia. Macedonia experienced $8.6 \%$ fall in the Gini index from 42.8 in 2009 to $34.2 \%$ in 2017 , while in Montenegro this index decreased only by $2.4 \%$ (from 41.2 in 2012 to $38.8 \%$ in 2014). The highest Gini index in Serbia was in 2014 and 2015 (40.5\%), which decreased by $4.3 \%$ in two years: $36.2 \%$ in 2017 .

The next section presents the methodology and statistical tools employed for evaluating the FDI inward flows effects on labour force indicators. 


\section{Econometric approach}

The analytical part of the research is aimed to present procedure for estimation of the impact of FDI inward flow on the segments of the labour market. Linear Mixed-Effects Model (LMM) is determined to estimate the overall impact of FDI inward flow on workers' indicators in transition economies in the period from 2000 to 2017.

In order to understand LMM, it is necessary to acknowledge the general concept of linear regression. Definition of linear regression is the following: $y=X \beta+\varepsilon$ where $y$ is the vector, $X$ is the known covariation matrix, $\beta$ is the vector of unknown coefficients, and $\varepsilon$ is the vector of random errors of the overall regression model (known as "regression error"). It can be assumed that each measure is connected with some random effect that has not been measured or observed, and label it as $\alpha$. If there is an observation $\mathrm{y}_{\mathrm{ij}}$ of $i$-person in $j$-time with the $\alpha_{\mathrm{i}}$ as random effect interconnected with $i$-person, the model will be the following: $\mathrm{y}_{\mathrm{ij}}=\mathrm{x}_{\mathrm{ij}} ; \beta+\alpha_{\mathrm{i}}+\varepsilon_{\mathrm{ij}}$. This last adopts the formulation of LMM. Therefore, the general definition of LMM is the following: $y=X \beta+Z \alpha+\varepsilon$, where $y$ is the vector of observations, $\beta$ is the vector of unknown regression coefficients called also fixed effects, $\alpha$ is the vector of random effects, $\mathrm{X}$ and $\mathrm{Z}$ are the known covariation matrixes that connect elements of the vector $\beta$ with the elements of the vector $\mathrm{y}$, and $\varepsilon$ is the vector of random errors.

The difference between ANOVA or multiple linear regression and LMM is that LMM includes not only fixed effects but also random effects. The inclusion of random effects is usual in the studies where the measures are correlated, while allowing control of the additional sources of variability. This is one of the reasons why the control variables are not required. The outcome of measures are dependent variables while the factors that impact measures are independent variables. The advantage of LMM is the model's ability to deal with missing values. When there are missing values in time series, as is the case here, LMM is often preferred over more common or traditional approaches such as simple linear regression, multiple linear regression, ANOVA, or similar. LMM belongs to regression analysis. The main goal of regression analysis is to predict the value of unknown variable(s) on the basis of the value of known variable(s). The unknown and known variables should be at least theoretically related to each other, in order to give sense and purpose to the analysis. Their relation can be deterministic (functional) and statistical (stochastic). By creating the regression model and mathematical functions, the correlation between variables is represented symbolically and describes the behaviour of observations in the real functional conditions. The correlation between variables is determined through theoretical and empirical knowledge about them and about their nature and relationship. 
LMM is developed based on the circumstances that the model does not require the balanced data. Random effects are included into the models given the fact that the effect of independent variables on dependent variable may differ from country to country. The models contain random intercepts as well, because each country in the sample exhibits its own trend of workers' indicators. Therefore, the models estimate fixed effects, random intercepts and random effects in each country in the sample. Akaike's Information Criteria (AIC) is used to search for the best model fit. The general formula for calculating fit criterion AIC is the following:

$$
A I C=N \ln \left(\frac{S S E}{N}\right)+2 K
$$

where: AIC - Akaike's Information Criteria, $\mathrm{N}$ - number of observations, $\ln -$ natural logarithm, SSE - sum of squared errors, K - number of parameters (fitted) +1 . The formula for calculating the sum of squared differences between observations and group's mean is the following:

$$
S E E=\sum_{i=1}^{n} x_{\mathrm{i}}^{2}-\frac{1}{n}\left(\sum_{i=1}^{n} x_{\mathrm{i}}\right)^{2}
$$

or

$$
S E E=\sum_{\mathrm{i}=1}^{\mathrm{n}}\left(\mathrm{x}_{\mathrm{i}}-\overline{\mathrm{x}}\right)^{2}
$$

where: $n-$ number of observations, $x_{i}-$ value of $i^{\text {th }}$ observation, $\bar{x}-$ mean of all observations.

IBM SPSS software version 23 is used to perform the LMM in order to estimate the relationship among workers' indicators and FDI inward flow in the countries covered by the study. All the chosen independent variables show their effects on the dependent variable in $t$ time for $i$ country. According to Heck, Thomas and Tabata (2014), the econometric modelling is based on the LMM general specification (different from the previous one only in regards to the symbols; the symbols $\alpha, \beta$ are typical for simple and multiple linear regression, while the symbols $\gamma, \mu$ are typical for LMM):

$$
\mathrm{y}=\mathrm{X} \gamma+\mathrm{Z} \mu+\varepsilon
$$

where: $\mathrm{y}$ - dependent variable, $\mathrm{X}$ - design matrix for fixed effects, $\gamma-$ unknown fixed effect parameter vector, $\mathrm{Z}$ - design matrix for random effects, $\mu$ - unknown random effect parameter vector, $\varepsilon$ - unknown error vector.

For normalizing the distribution of variables $(\mathrm{N}=(0, \sigma 2))$, the values of the dependent and independent variables have been transformed in natural logarithms (ln). The explicit model specification of each model in the study is as follows: 


$$
\begin{aligned}
& \ln \Delta \text { Empl }_{\mathrm{ti}}=\gamma_{00}+\gamma_{10} \ln \Delta \text { FDIif } 1_{\mathrm{t}}+\gamma_{20} \ln \Delta \text { FDIif } 2_{\mathrm{t}}+\gamma_{30} \ln \Delta \text { FDIif3 }_{\mathrm{t}}+ \\
& +\mu_{1 \mathrm{i}} \ln \Delta \text { FDIifl }_{\mathrm{ti}}+\mu_{2 \mathrm{i}} \ln \Delta \text { FDIif }_{\mathrm{ti}}+\mu_{3 \mathrm{i}} \ln \Delta \text { FDIif }_{\mathrm{ti}}+\mu_{0 \mathrm{i}}+\varepsilon_{\mathrm{ti}} \\
& \ln \Delta \text { Wage }_{\mathrm{ti}}=\gamma_{00}+\gamma_{10} \ln \Delta \text { FDIif } 1_{\mathrm{t}}+\gamma_{20} \ln \Delta \text { FDIif }{ }_{\mathrm{t}}+\gamma_{30} \ln \Delta \text { FDIif }{ }_{\mathrm{t}}+ \\
& +\mu_{1 \mathrm{i}} \ln \Delta \text { FDIifl }_{\mathrm{ti}}+\mu_{2 \mathrm{i}} \ln \Delta \text { FDIif }_{\mathrm{ti}}+\mu_{3 \mathrm{i}} \ln \Delta \text { FDIif }_{\mathrm{ti}}+\mu_{0 \mathrm{i}}+\varepsilon_{\mathrm{ti}} \\
& \operatorname{lnGini}{ }_{\mathrm{ti}}=\gamma_{00}+\gamma_{10} \ln \Delta \text { FDIif }_{\mathrm{t}}+\gamma_{20} \ln \Delta \text { FDIif }_{\mathrm{t}}+\gamma_{30} \ln \Delta \text { FDIif3 }_{\mathrm{t}}+ \\
& +\mu_{1 \mathrm{i}} \ln \Delta \text { FDIifl }_{\mathrm{ti}}+\mu_{2 \mathrm{i}} \ln \Delta \text { FDIif }_{\mathrm{ti}}+\mu_{3 \mathrm{i}} \ln \Delta \text { FDIif }_{\mathrm{ti}}+\mu_{0 \mathrm{i}}+\varepsilon_{\mathrm{ti}}
\end{aligned}
$$

where: $\mathrm{y} \rightarrow \ln \Delta$ Empl (1), $\ln \Delta$ Wage (2), and $\ln \Delta$ Gini (3) - dependent variables for each model, $\gamma_{00} \rightarrow$ grand intercept, $X \rightarrow \gamma_{10} \ln \Delta$ FDIifl $_{t}, \gamma_{20} \ln \Delta \mathrm{FDIif}_{\mathrm{t}}$, and $\gamma_{30} \ln \Delta$ FDIif $_{\mathrm{t}}-$ fixed effects, Z $\rightarrow \mu_{1 \mathrm{i}} \ln \Delta$ FDIif $_{\mathrm{ti}}, \quad \mu_{2 \mathrm{i}} \ln \Delta$ FDIif $2_{\mathrm{ti}}, \quad$ and $\mu_{3 \mathrm{i}} \ln \Delta$ FDIif $_{\mathrm{ti}}-$ random effects, $\mu_{0 \mathrm{i}} \rightarrow$ random residuals, $\varepsilon_{\mathrm{ti}} \rightarrow$ regression residuals

Therefore, the authors' intention is to estimate the quantitative relation between dependent and independent variables, grounded on the estimated models.

The models estimate the effect of $\Delta$ FDIif and lagged $\Delta$ FDIif on $\Delta$ Empl and on $\Delta$ Wage, while adjusting for correlation due to repeated observations on each variable over each year. The lagged terms were used based on the theoretical

\begin{tabular}{|c|c|c|c|c|c|}
\hline Country & Year & $\begin{array}{l}\text { Variables in } \\
\text { millions of } \\
\text { dollars }\end{array}$ & $\begin{array}{l}\text { Variation of variables in millions of } \\
\text { dollars from } t \text { to } t+1\end{array}$ & $\begin{array}{l}\text { Variables in } \\
\text { percentages }\end{array}$ & $\begin{array}{l}\text { Variation of } \\
\text { variables in } \% \\
\text { from } t \text { to } t+1\end{array}$ \\
\hline A & $\mathrm{t}$ & mln_dollars & & $\%$ & \\
\hline A & $\mathrm{t}+1$ & mln_dollars & $\frac{m l n_{-} \text {dollarst }+1}{m l n_{-} \text {dollarst }}-1$ & $\%$ & $\frac{\% t+1}{\% t}-1$ \\
\hline B & $\mathrm{t}$ & mln_dollars & & $\%$ & $\% t+1$ \\
\hline B & $\mathrm{t}+1$ & mln_dollars & $\frac{m l n \_ \text {dollarst }+1}{m l n \_ \text {dollarst }}-1$ & $\%$ & $\frac{\% t}{\%}-1$ \\
\hline
\end{tabular}
assumption that FDIif requires time to show the real effects of its performance in the country. In order to assure easier reproducibility of the research, Table 3 shows the design of variables transformation related to the annual changes in variables.

Table 3: Transformation and trusted-lagged-terms

Source: Author's calculation

Therefore, all variables' values are presented in percentages. The impossibility of the \%changes transformation of the Gini index from year to year is due to the insufficient official data available. Also, countries apply 
different methods of measuring expenditure in household surveys (Booth 2019).

Before the results are presented, the descriptive statistics is shown in Table 4. Descriptive statistics show the descriptive summary of the data set used in this research.

Table 4: Descriptive statistics

\begin{tabular}{|c|c|c|c|c|c|c|c|}
\hline & $\mathbf{N}$ & Minimum & Maximum & Mean & & Std. Dev. & Variance \\
\hline & Statistic & Statistic & Statistic & Statistic & Std. Error & Statistic & Statistic \\
\hline Year & 306 & 2000 & 2017 & 2008.5 & 0.297 & 5.197 & 27.005 \\
\hline & & & & 3147.9 & & 8373.83 & 7012108 \\
\hline FDI inward flow & 288 & -4749 & 75856 & 6 & 493.433 & 4 & 9 \\
\hline$\Delta$ FDI_if & 270 & -1.35 & 32.79 & 0.5684 & 0.14798 & 2.43149 & 5.912 \\
\hline$\Delta$ FDI_if_1 & 253 & -1.35 & 32.79 & 0.6019 & 0.15744 & 2.50427 & 6.271 \\
\hline$\Delta$ FDI_if_- 2 & 236 & -1.35 & 32.79 & 0.6335 & 0.16811 & 2.58261 & 6.67 \\
\hline$\Delta$ FDI_if_3 & 219 & -1.35 & 32.79 & 0.6703 & 0.17857 & 2.64257 & 6.983 \\
\hline $\ln \Delta$ FDIif & 153 & -4.77 & 3.49 & -0.6569 & 0.10434 & 1.29066 & 1.666 \\
\hline $\ln \Delta$ FDIif1 & 145 & -4.77 & 3.49 & -0.5937 & 0.10287 & 1.23872 & 1.534 \\
\hline $\ln \Delta$ FDIif2 & 137 & -4.77 & 3.49 & -0.5843 & 0.10651 & 1.24669 & 1.554 \\
\hline $\ln \Delta$ FDIif3 & 133 & -4.77 & 3.49 & $\begin{array}{l}-0.5902 \\
51.580\end{array}$ & 0.10792 & 1.24456 & 1.549 \\
\hline Empl & 306 & 32.18 & 67.52 & 5 & 0.53769 & 9.40576 & 88.468 \\
\hline$\Delta$ Empl & 289 & -4.46 & 3.11 & 0.1117 & 0.05495 & 0.93407 & 0.872 \\
\hline $\ln \Delta \mathrm{empl}$ & 183 & -4.61 & 1.13 & $\begin{array}{l}-1.0911 \\
63.865\end{array}$ & 0.08683 & $\begin{array}{l}1.17457 \\
18.3779\end{array}$ & 1.38 \\
\hline Wage & 306 & 24.74 & 96.83 & 7 & 1.0506 & 5 & 337.749 \\
\hline$\Delta$ Wage & 289 & -6.93 & 11.8 & 0.3987 & 0.1161 & 1.97365 & 3.895 \\
\hline $\ln \Delta$ Wage & 175 & -4.34 & 2.47 & $\begin{array}{l}-0.4145 \\
31.928\end{array}$ & 0.10392 & 1.37472 & 1.89 \\
\hline Gini & 185 & 16.2 & 42.8 & 6 & 0.37769 & 5.13712 & 26.39 \\
\hline lnGini & 185 & 2.79 & 3.76 & 3.4499 & 0.01242 & 0.16888 & 0.029 \\
\hline $\ln \Delta$ Gini & 67 & -2.3 & 2.07 & -0.4087 & 0.14564 & 1.19208 & 1.421 \\
\hline $\begin{array}{l}\text { Valid } \\
\text { (listwise) }\end{array}$ & 0 & & & & & & \\
\hline
\end{tabular}

The next section is about to present and elaborate on results, and it compares the outcomes of previous research.

\section{Results and Discussion}

The results found are in percentages as the value representative of the annual changes in variables (see Table 3). Therefore, the impact of independent variables on the dependent variable is expressed in percentages.

After the best goodness of fit of the linear model is selected, the lowest AIC value is detected for each model:

(1) For $\ln \Delta \mathrm{Empl}_{\mathrm{ti}}$ AIC is 35,311 ,

(2) For $\ln \Delta$ Wage $_{\text {ti }}$ AIC is 46,875 ,

(3) For $\operatorname{lnGini}_{\text {ti }}$ AIC is $-13,978$.

The econometric findings of the impact of FDI inward flow are presented in Table 5, Table 6, and Table 7. 
Table 5: Impact of foreign direct investment inward flow on employment rate

\begin{tabular}{|c|c|c|c|c|c|c|c|}
\hline \multicolumn{8}{|c|}{ Estimates of Fixed Effects(a) } \\
\hline \multirow[t]{3}{*}{ Parameter } & \multirow[t]{3}{*}{ Estimate } & \multirow[t]{3}{*}{ Std. Error } & \multirow[t]{3}{*}{ Df } & \multirow[t]{3}{*}{$\mathbf{t}$} & \multirow[t]{3}{*}{ Sig. } & \multicolumn{2}{|c|}{ 95\% Confidence Interva } \\
\hline & & & & & & Lower & Upper \\
\hline & & & & & & Bound & Bound \\
\hline Intercept & -0.806 & 0.171 & 6.083 & -4.722 & 0.003 & -1.222 & -0.390 \\
\hline $\ln \Delta$ FDIif1 & 0.082 & 0.002 & 2.000 & 33.388 & 0.001 & 0.072 & 0.093 \\
\hline $\ln \Delta$ FDIif2 & 0.101 & 0.123 & 7.020 & 0.821 & 0.439 & -0.189 & 0.391 \\
\hline $\ln \Delta$ FDIif3 & 0.030 & 0.000 & 15606132 & 130562.584 & 0.000 & 0.030 & 0.030 \\
\hline \multicolumn{8}{|c|}{ a. Dependent Variable: $\ln \Delta$ empl. } \\
\hline
\end{tabular}

Source: Authors' calculation

Table 5 presents the estimated impact of the FDI inward flow on employment rate in transition countries. If there is a change in independent variable (x) by $1 \%$, it is expected that the dependent variable (y) will change by coefficient of independent variable $\%(\gamma 1)$, while keeping other independent variables constant. Therefore, the results show that if FDI inward flow increases by $1 \%$ after one year ( $\ln \Delta \mathrm{FDIif1})$, employment rate will increase by $0.082 \%(\mathrm{p}=.001)$. The positive impact of FDI inward flow on employment rate after one year represents mostly the positive activity of foreign companies in a transition country. This is caused by the implied hiring of new labour force during the initial phase of a company once it is established in a country. Not later than in the second year, the impact of FDI inward on employment rate is positive $(0.101 \%)$ but not statistically significant $(\mathrm{p}=.439)$, presuming that a foreign company stops with hiring new labour force and is dedicated to production. In case a foreign company successfully exercises business activities in a transition country, it requires some additional labour force. In such a case, if the FDI inward flow increases by $1 \%$, it will positively affect employment rate in the third year, although with lower number $(0.03 \%)$ and statistical significance $(\mathrm{p}=.000)$. The findings regarding positive impact of FDI on employment rate in transition economies is in accordance with the theoretical and empirical assumptions with ex. Jude and Silaghi (2016), Stanisic (2008), while contrary to ex. Grahovac and Softic (2017); Zdravkovic and Martinovic (2016); Sabic et al. (2012).

Table 6 presents the estimated impact of FDI inward flow on paid wages and salaries in transition economies. According to the results, foreign companies pay wages and salaries to their hired workers when they are established in transition economies. If FDI inward flow increases by $1 \%$, paid salaries and wages in transition economies will grow by $0.138 \%(\mathrm{p}=.000)$ after 2 years, and by $0.178 \%(\mathrm{p}=.000)$ in the third year of business of a foreign 
company in a host country. Therefore, the positive impact of FDI inward flow on paid wages and salaries in transition economies is constantly growing, meaning that foreign investors are increasingly likely to pay wages and salaries to employees. The previous statement is in accordance with Arnal and Hijzen (2008).

Table 6: Impact of foreign direct investment inward flow on paid wages and salaries

\begin{tabular}{lccccccc}
\hline \multicolumn{2}{l}{ Estimates of Fixed Effects(a) } & \multicolumn{1}{l}{} \\
\hline \multicolumn{1}{l}{ Parameter } & Estimate & Std. Error & Df & t & Sig. & 95\% Confidence Interval \\
\hline Intercept & -0.293 & 0.136 & 52.212 & -2.151 & 0.036 & -0.566 & -0.020 \\
$\ln \Delta$ FDIif1 & -2.554 &. &. &. &. &. &. \\
$\ln \Delta$ FDIif 2 & 0.138 & 0.006 & 52.212 & 21.327 & 0.000 & 0.125 & 0.151 \\
$\ln \Delta$ FDIif3 & 0.178 & 0.025 & 52.212 & 7.028 & 0.000 & 0.127 & 0.229 \\
a. Dependent Variable: $\ln \Delta$ Wage. & & & & & &
\end{tabular}

Source: Authors' calculation

Table 7: Impact of foreign direct investment inward flow on income inequality

\begin{tabular}{|c|c|c|c|c|c|c|c|}
\hline \multicolumn{8}{|c|}{ Estimates of Fixed Effects(a) } \\
\hline \multirow[t]{2}{*}{ Parameter } & \multirow{2}{*}{ Estimate } & \multirow{2}{*}{ Std. Error } & \multirow[t]{2}{*}{ Df } & \multirow[t]{2}{*}{$\mathbf{t}$} & \multirow[t]{2}{*}{ Sig. } & \multicolumn{2}{|c|}{ 95\% Confidence Interval } \\
\hline & & & & & & Lower Bound & Upper Bound \\
\hline Intercept & 3.384 & 0.068 & 8.367 & 49.425 & 0.000 & 3.227 & 3.541 \\
\hline $\ln \Delta$ FDIif1 & 0.009 & 0.015 & 3.289 & 0.588 & 0.594 & -0.036 & 0.053 \\
\hline $\ln \Delta$ FDIif2 & -0.019 & 0.018 & 3.815 & -1.065 & 0.350 & -0.071 & 0.032 \\
\hline $\ln \Delta$ FDIif3 & 0.003 & 0.009 & 8.119 & 0.289 & 0.780 & -0.019 & 0.024 \\
\hline \multicolumn{8}{|c|}{ a. Dependent Variable: lnGini. } \\
\hline
\end{tabular}

Source: Authors' calculation

Table 7 shows the estimation of the impact of FDI inward flow on income inequality in transition countries. While the estimated parameters show the negative and positive impact of FDI inward flow on income inequality, the results are not statistically significant. According to the statistical rules and practice, the statistical significance may not be relevant in the short period of time, the reason why the other parameters shall be taken into consideration, such as confidence interval. Moreover, the confidence intervals vary between negative and positive values, making it difficult to (at least) stress the prevalence of the positive or negative impact of the variable. On average, if the FDI inward flow increases by $1 \%$, it may negatively impact income inequality in transition countries after one year $\left(0.009 \%, \mathrm{p}=.594, \mathrm{CI}_{95 \%}=-0.036,0.053\right)$, 
and after three years $\left(0.003 \%, \mathrm{p}=.780, \mathrm{CI}_{95 \%}=-0.019,0.024\right)$. However, after two years, there is an impact of $-0.019 \%(\mathrm{p}=.350)$ meaning that FDI inward flow decreases the income inequality, which is a positive effect (Obradovic Lojanica 2015). Since the CI varies between negative and positive values, the conclusion is that the impact of FDI inward flow on income inequality measured with the Gini index in transition countries is uncertain. FDI inward increases wage inequality in transition economies (Figini - Gorg 2011; Milanovic - Ersado 2008), reserving the complexity of the model and possible presence of non-linear effect (Alili 2015). The uncertain impact of FDI on the Gini index found here is in line with the findings of Alili and Adnett (2018).

In summary, the estimates show the overall minimal positive effect of FDI inward flow on employment and wages. FDI inward contributes in a small measure to increasing wage inequality in transition economies, though the overall effects on income inequality remain statistically ambiguous. Moreover, time effect and structural changes in a country cause the variation (increase and decrease) in inequality (Milanovic 2015; Sohinger - Harrison 2004; Vorobyov - Zhukov 2000).

Foreign investments contribute to both financial domestic capital and labour force. The contribution to labour force is both positive and negative. The positive impact is reflected in the import of new technology and knowledge that are available to domestic labour force, as well as the higher and regular pay of wages and salaries. The negative impact is that a part of active labour force does not use new technologies, or there is no personal need for that, or they don't have sufficient background for using new technologies. Consequently, there is a decrease in employment, at the first instance, causing unpaid salary and increase in discrepancy and inequality. The quality of life of labour force is directly impacted. In this paper, the quality of life is discussed based on the research results. The labour force indicators are interconnected and affect the quality of life of labour force both directly and indirectly. Besides the impact of a chosen indicator, many other factors impact the quality of life of the labour force, such as the size and sectoral fields of a foreign company. In the companies where the turnover is likely high and the differences in pays are large, there is an impact on social life, therefore on the quality of life of labour force. In extreme cases, the ruined quality of life results in poor health of labour force. When importing new technology and management practices, there is a decrease in employment and increase in education. This is accompanied with different mental approaches that local employees may or may not be capable to adopt or adapt to. In the literature, one of the definitions of this aspect is intercultural gaps. Intercultural gaps, the difficulties caused by being unable to immediately adapt and the requirements of foreign investor to change attitudes, have effects on work, performances, social life and health. The 
dilemma whether the FDI increases or decreases the inequality persisted in this paper. FDI affect the increase of income inequality mostly because of higher wages and salaries, import of new technology and increased productivity.

The need of transition economies to attract and host FDI is due to the lack of capital to finance domestic economic issues, such as a lack of technology and knowledge to lunch domestic projects. The fewer transition economies' capacities to self-finance, the greater dependency on FDI, and the more labour force and its quality of life is impacted. This kind of impact comes at the first instance (which is tangible) as an increase in wage discrepancies and income inequality, resulting in changes of the quality of life of workers. Some of workers were able to receive greater salaries, while some of them require social care or low paid job. The quality of life improves in the first category, while the second category may struggle, need further education, but be unable to finance their education. The quality of life implies the social life of labour force, which may change due to the above mentioned reasons: the first category tends to focus on work, additional education and self-orientation, while the second category experiences lack of employment or low salaries.

\section{Conclusion}

The purpose of this paper was to estimate the impact of FDI inward flow on the three main labour force parameters: employment rate, paid wage and salaries, and income inequality, using linear mixed-models effects and discuss results in terms of the quality of life of the labour force.

The results of this research clarify that the FDI inward flow is the reason for higher employment, greater paid wages and narrowed income inequality (not statistically significant), even if in low percentage changes. Regardless of statistical insignificance for income inequality outcome, it should be noted that labour market is subject to other elements and not to FDI inward flow only. Considering that foreign capital requires time to show different effects on the labour market, the application of time lags is justified. Keeping focus on the main outcomes, some short conclusion remarks could be listed. In terms of model outcome, the results are the following. For employment, after one year of FDI inward flow performing in a country under assumption of its $1 \%$ change, the employment rate increases by $0.082 \%$ with statistical significance $(\mathrm{p}=.001)$. After three years of FDI performance and its increase of $1 \%$, employment rate will increase by $0.03 \%(\mathrm{p}=.000)$. For paid wages and salaries, if FDI inward flow increases by $1 \%$, paid salaries and wages in transition economies will grow by $0.138 \%(\mathrm{p}=.000)$ after 2 years, and $0.178 \%(\mathrm{p}=.000)$ in the third year of a foreign company performing in a host country.

In the first place, FDI inward flows slightly increases the employment rate. Employment rate indicates the employed portion of the population, and how

Sociológia 53, 2021, No. 3 
economy is efficient in providing job to the people in search for employment. Although high employment rate is a positive data, lower employment rate may be positive. Lower employment rate is welcome especially in the countries with a high young-population ratio, which leads to obtaining higher education.

In the second place, FDI inward flow increases paid wage and salaries as well. The analysis showed that from 2000 to 2017, in some countries, the responsibility of employers towards their employees was improved, while some other countries were stagnating. The effects of transition (economic, political, cultural, etc.) is supposed to be the major reason for the abovementioned.

In the third place, the impact of FDI inward flow on income inequality is uncertain. The Gini index per se may be a critical indicator of income inequality. Generally speaking, the Gini index measures relative rather than absolute wealth. Moreover, each country may have different methodology of calculating a proper Gini index, given their different understanding of living standards and economic models. The population itself may be an issue as well, due to the different consumption structure and needs of the population.

Finally, the main recommendation for policy-makers is the greater engagement in data collection, and problem-solving methodologies. The goal is to update and create national policies and strategies, and employ high-skilled professionals for that purpose. When it comes to unavailable national resources (human, capital, or financial), policy-makers should plan and implement measures of efficient employment, as well as turn their attention on regional and international collaboration and cooperation. Despite the overall beneficial effects of inward FDI on labour markets in transition economies, the governments should target the increase in the supply of skilled labour.

Transition economies with high dependency on FDI should carefully attract, evaluate and negotiate, rather accept all foreign investor's conditioning. To do so, a transition economy should improve the functionality (coordination) of all interested parties (institutions, politicians, workers' representatives, rules and laws) involved in the procedure of attracting and establishing a foreign investor. The entrance of a new foreign company should satisfy economic, financial, political and social interests of a host county. As a key globalisation factor, new FDI should be negotiated carefully because of its direct (employment, wages) and indirect (fiscal policy, host economy social life, culture and quality of life) effect. Moreover, prior to accepting the financially promising inward FDI, transition economies should thoughtfully and gradually establish structural reforms such as market and fiscal reforms accompanied with laws and rules. This would contribute to the stronger negotiation power with foreign investors. High dependency on FDI gives room to high impact on the social life which therefore may dramatically change the quality of life of labour force. Last but not the least, the governments and institutions should 
thoughtfully embrace structural changes, as well as take control over FDI in order to avoid political instability. Political instability may lead to social disruptions, and consequently to decrease in FDI opportunities.

The authors think that future research may cover the valuation of the FDI inward flow beneficiaries, the implication of inadequate countries' governance, legislation and correct political planning, requirement of new ideas, strategies and programmes in relation to the FDI inward flow.

Limitations of this research are as follows. The overmissing values in the official time series for the Gini index prevent this analysis from evaluating the impact of inward FDI on the changes in the Gini index converted in natural logarithms. Further research could focus on calculation of the Gini index year by year for all the countries in the sample. Moreover, future researchers could attempt to reason over the low wage effects and massive migration in relation to multinational companies. Similarly, the researchers could seek to link the structural problems with labour market problems (endogenous growth cycle, counties' growth model, and labour market policies). Finally, the evaluation of the impact of the inward FDI on labour force and the quality of life of labour force including the period of coronavirus crises shall take place in the future research attempts.

Milica Peric is a PhD candidate in Economics (Contemporary Business Management) at the Singidunum University, whereas BSc and MSc studies she finished at the University of Parma. Her research interest covers international economics, HR management, and macroeconomic analysis. She has collaborated on several international projects and published several original research papers, including her master theses.

Sanja Filipovic is a full professor at the Singidunum University and a Principal Research Fellow at the Institute of Social Sciences. She is an economist and her research interest covers macroeconomic analysis, international economics and sustainable development. She has broad project management experience and she published more than hundred bibliographical units, including seven books.

\section{REFERENCES}

ALILI, Z. M., 2014: Inward Foreign Direct Investment and Wage Inequality in Macedonia. Eastern European Economics 52(5): 56-86. https://doi.org/10.1080/00128775.2014.1004265

ALILI, Z. M., 2015: An Empirical Investigation of the Role of FDI on Wage Inequality in Transition Economies. The Eleventh International Conference: Challenges of Europe: Growth, competitiveness and inequality.

Sociológia 53, 2021, No. 3 
ALILI, Z. M. - ADNETT, N., 2018: Did FDI Increase Wage Inequality in Transition Economies? International Journal of Social Economics 45(9): 1283-1304. https://doi.org/10.1108/IJSE-09-2017-0373

ARNAL, E. - HIJZEN, A., 2008: The Impact of Foreign Direct Investment on Wages and Working Condition. OECD Social, Employment and Migration Working Papers No. 68. https://doi.org/10.1787/1815199X

BARTLETT, W., 2007: Economic Transition in Serbia since 2000: Trends and Prospects. Journal of the Western Balkans Security Observer 7-8: 29-37.

BEECHLER, S. - WOODWARD, I. C., 2009: The Global "War for Talent". Journal of International Management 15: 273-285. https://doi.org/10.1016/j.intman.2009.01.002

BEVAN, A. - ESTRIN, S., 2000: The Determinants of FDI in Transition Economies. Discussion Paper No. 2638, Center for Economic Policy Research: London.

BHANDARI, B., 2007: Effect of Inward Foreign Direct Investment on Income Inequality in Transition Countries. Journal of Economic Integration 22(4): 888-928. https://doi.org/10.11130/jei.2007.22.4.888

BOGLIACCINI, A. J. - EGAN, J. W. P., 2017: Foreign Direct Investment and Inequality in Developing Countries: Does Sector Matter? Economics and Politics 29: 209-236. https://doi.org/10.1111/ecpo.12098

BOOTH, A., 2019: Measuring poverty and income distribution in Southeast Asia". Asian Pacific Economic Literature, 1-18. https://doi.org/10.1111/apel.12250

BRADA, J. C. - KUTAN, A. M. - YIGIT, T. M., 2006: The Effects of Transition and Political Instability on Foreign Direct Investment Inflows: Central Europe and the Balkans. Economics of Transition 14(4): 649-680. https://doi.org/10.1111/j.14680351.2006.00272.x

BRINCIKOVA, Z. - DARMO, L., 2014: The Impact of FDI Inflow on Employment in V4 Countries. European Scientific Journal 1: 245-252.

BRUNO, G. S. F. - CRINO, R. - FALZONI, A. M., 2012: Foreign Direct Investment, Trade, and Skilled Labour Demand in Eastern Europe. Labour 26(4): 492-513. https://doi.org/10.1111/labr.12001

BUCKLEY, P. - WANG, C. C. - CROSS, A., 2002: FDI, Regional Differences and Economic Growth: Panel Data: Evidence from China. Transnational Corporations 11(1): 1-28.

CHIU, Y. B. - LEE, C. C., 2019: Financial Development, Income Inequality, and Country Risk. Journal of International Money and Finance 93: 1-18. https://doi.org/10.1016/j.jimonfin.2019.01.001

DELIBASIC, M., 2019: The Impact of Neoliberal Economic Policy on Economic Development in the Countries of Southeast Europe. Transformations in business \& economics 18(2): 323-337.

DEMENA, B. A. - MURSHED, S. M., 2018: Transmission Channels Matter: Identifying Spillovers from FDI. Journal of International Trade and Economic Development 27(7): 701-728. https://doi.org/10.1080/09638199.2018.1439083.

DERADO, D., 2013: Determinants of FDI in Transition Countries and Estimation of the Potential Level of Croatian FDI. Financial theory and practice 37(3): 227-258. https://doi.org/10.3326/fintp.37.3.1 
DOGRU, B., 2012: The Effect of Institutional Variables on FDI Inflows: Evidence from Upper-Middle Income Countries. Global Journal of Economics and Business Studies 1(1): 1-12.

ESTRIN, S., 2017: Foreign Direct Investment and Employment in Transition Economies. Has FDI into Transition Countries had the Expected Economic Effects? IZA World of Labor 330. https://doi.org/10.15185/izawol.330

ESTRIN, S. - UVALIC, M., 2014: FDI into Transition Economies. Are the Balkans Different? Economics of Transition 22(2): 281-312. https://doi.org/10.1111/ecot.12040

FEENSTRA, R. C. - HANSON, G., 1997: Foreign Direct Investment and Relative Wages: Evidence from Mexico's Maquiladoras. Journal of International Economics 42: 371-393. https://doi.org/10.1016/S0022-1996(96)01475-4

FIGINI, P. - GORG, H., 2011: Does Foreign Direct Investment Affect Wage Inequality? An Empirical Investigation. World Economy, 34(9): 1455-1475. https://doi.org/10.1111/j.1467-9701.2011.01397.x

FILIPOVIC, S. - MILJKOVIC, M., 2010: Restructuring and Privatization in the Energy Sector of the Republic of Serbia. Poslovna ekonomija 4(2), 15-30.

FILIPOVIC, S. - MILJKOVIC, M., 2014: Transition Economies During Global Economic Crisis: A Difference in Differences Approach. Industrija 42(3): 23-39. https://doi.org/10.5937/industrija42-6944

GRAHOVAC, D. - SOFTIC, S., 2017: Impact of the FDI on Unemployment Rate in Countries of West Balkan. Review of Innovation and Competitiveness 3(2): 65-82. https://doi.org/10.32728/ric.2017.32/4

GROTKOWSKA, G. - WINCENCIAK, L. - GAJDEROWICZ, T., 2018: PublicPrivate Wage Differential in a Post-Transition Economy. Economics of Transition 26(3): 495-522. https://doi.org/10.1111/ecot.12149

HALE, G. - XU, M., 2016: FDI Effects on the Labor Market of Host Countries. Federal Reserve Bank of San Francisco, Working Paper 2016-25. https://doi.org/10.24148/wp2016-25

HARDY, W. - KEISTER, R. - LEWANDOWSKI, P., 2018: Educational Upgrading, Structural Change and the Task Composition of Jobs in Europe". Economics of Transition 26(2): 201-231. https://doi.org/10.1111/ecot.12145

HECK, R. H. - THOMAS, S. L. - TABATA, L. N., 2014: Multilevel and Longitudinal Modeling with IBM SPSS. Routledge: New York and London. https://doi.org/10.4324/9780203701249

HEDVICAKOVA, M. - SOKOLOVA, M. - MOHELSKA, H., 2018: The Impact of Economic Growth on Wages and the Supply of Employee Benefits in the Czech Republic. Transformations in business \& economics 17(3): 140-154.

HUBNER, G., 2011: Foreign Direct Investment in Azerbaijan - the Quality of Quantity. Caucasus Analytical Digest 28: 2-6.

IWASAKI, I. - TOKUNAGA, M., 2016: Technology Transfer and Spillovers from FDI in Transition Economies: A Meta-Analysis. Journal of Comparative Economics 44(4): 1086-1114. https://doi.org/10.1016/j.jce.2016.10.005

JOHNSON, A., 2006: FDI Inflows to the Transition Economies in Eastern Europe: Magnitude and Determinants. CESIS Working Paper No. 59. 
JUDE, C. - SILAGHI, I. P. M., 2016: Employment Effects of Foreign Direct Investment: New Evidence from Central and Eastern European Countries. International Economics 145: 32-49. https://doi.org/10.1016/j.inteco.2015.02.003

KRAMMER, S. M. S., 2010: International R\&D Spillovers in Emerging Markets: The Impact of Trade and Foreign Direct Investment. Journal of International Trade and Economic Development 19(4): 591-623. https://doi.org/10.1080/09638190902792464

KURTISHI, K. S., 2013: The Effects of Foreign Direct Investments for Host Country's Economy. European Journal of Interdisciplinary Studies, Bucharest Economic Academy, 5(1): 26-38.

KURTOVIC, S. - TALOVIC, S. - DACIC, L., 2015: Panel Cointegration Analysis of Foreign Direct Investments and Average Net Wages: The Case of four Western Balkan Countries. G. \& L. E. R. 19(1): 1-36.

LE, Q. H. - HO, H. L. - MAI, N. C., 2019: The Impact of Financial Inclusion on Income Inequality in Transition Economies. Management Science Letters 9: 661672. https://doi.org/10.5267/j.msl.2019.2.005

LEE, J. W. -- BAIMUKHAMEDOVA, G. S. - AKHMETOVA, S., 2009: The Effects of Foreign Direct Investment on Economic Growth of a Developing Country: From Kazakhstan. Proceedings of the Academy for Economics and Economic Education: Allied Academies International Conference Las Vegas 12(2): 22-27.

LEE, S. - GARDNER, L. - JOHNSON, J., 2011: Impact of Foreign Direct Investment on Kazakhstan's Economy: A Boon or a Curse. International Journal of Business and Social Science 2(22).

LI, C. - LUO, Y., 2019: Spillover Effects of Foreign Direct Investment: Evidence from the West Midlands of England. Economic Issues 24(1): 1-19.

LIN, F., 2018: Cross-Country Diffusion of Ideology Via FDI. Economics of Transition 26(1): 3-34. https://doi.org/10.1111/ecot.12139

LU, Y. - TAO, Z. - ZHU, L., 2017: Identifying FDI Spillovers. Journal of International Economics 107: 75-90. https://doi.org/10.1016/j.jinteco.2017.01.006

MAH, J. S., 2012: Foreign Direct Investment, Labour Unionization and Income Inequality of Korea. Applied Economics Letters 19: 1521-1524. https://doi.org/10.1080/13504851.2011.637888

MELNYK, L. - KUBATKO, O. - PYSARENKO, S., 2014: The Impact of Foreign Direct Investment on Economic Growth: Case of Post Communism Transition Economies. Problems and Perspectives in Management 12(1): 17-24.

MILANOVIC, B., 2015: Global Inequality: A New Approach for the Age of Globalization. Harvard University Press Cambridge, Massachusetts. London, England.

MILANOVIC, B. - ERSADO, L., 2008: Reform and Inequality during the Transition: An Analysis Using Panel Household Survey Data, 1990 - 2005. World Bank Policy Research Working Paper, no. 4780, Washington, DC. https://doi.org/10.1596/18139450-4780

MRVA, M., 2020: Sociálny kapitál a subjektívna pohoda na Slovensku. Sociológia 52(2): 111-131. https://doi.org/10.31577/sociologia.2020.52.2.5 
MYCK, M. - OCZKOWSKA, M., 2018: Shocked by Therapy? Unemployment in the First Years of the Socio-Economic Transition in Poland and its Long-Term Consequences. Economics of Transition 26(4): 695-724.

https://doi.org/10.1111/ecot.12161

OBRADOVIC, S. - LOJANICA, N., 2015: Foreign Direct Investment and Income Inequality - Evidence from Developing Economies. The Annals of the Faculty of Economics in Subotica 51(34): 3-13.

ONARAN, O. - STOCKHAMMER, E., 2006: The Effect of FDI and Foreign Trade on Wages in the Central and Eastern European Countries in the Post-Transition Era: A Sectoral Analysis. Department of Economics Working Paper Series No. 94. WU Vienna University of Economics and Business.

PERIC, M., 2020: Impact of FDI Inflow on Average Wage and Employment in Serbia. Management 25(1):13-22. https://doi.org/10.7595/management.fon.2019.0007

PERIC, M., 2019: The Impact of FDI Inflow on Ex-Yugoslav Countries' Labour Markets. Paper Presented on the International Scientific Conference FINIZ, Singidunum University, Belgrade. https://doi.org/10.15308/finiz-2019-91-97

PERIC, M. - FILIPOVIC, S., 2018: Impact of Export Determinants on the Export Sector in Republic of Serbia. Industrija 46(2): 151-171. https://doi.org/10.5937/industrija46-17408

POPOVIC, G. - ERIC, O., 2018: Economic Development of the Western Balkans and European Union investments. Economic Research 31(1): 1539-1556. https://doi.org/10.1080/1331677X.2018.1498009

SABIC, D. - VUJADINOVIC, S. - MILINCIC, M. - GOLIC, R. - STOJKOVIC, S. JOKSIMOVIC, M. - FILIPOVIC, D. - SECEROV, V., 2012: The Impact of FDI on the Transitional Economy in Serbia - Changes and Challenges. Acta Polytechnica Hungarica 9(3): 65-84.

SAUVANT, K., 2005: New Sources of FDI: The BRICs. Outward FDI from Brazil, Russia, India and China. Journal of World Investment and Trade 6(5): 639-709.

SHAHBAZ, M. - BHATTACHARYA, M. - MAHALIK, M. K., 2017: Finance and Income Inequality in Kazakhstan: Evidence Since Transition with Policy Suggestions. Journal of Applied Economics 49(52): 5337-5351. https://doi.org/10.1080/00036846.2017.1305095

SHENGELIA, T. - KOZAK, Y. - KIRKITADZE, Z., 2020: FDI Motivation Effects on Host Countries. World economy and international economic relations 3: 15-20.

SOHINGER, J. - HARRISON, W. G., 2004: The Implications of Foreign Direct Investment for Development in Transition Countries: Challenges for the Croatian Economy. Eastern European Economics 42(1): 56-74. https://doi.org/10.1080/00128775.2004.11041069

STANISIC, N., 2008: Do Foreign Direct Investments Increase the Economic Growth of South-Eastern European Transition Economies? South-Eastern Europe Journal of Economics 1: 29-38.

TAYLOR, K. - DRIFFIELD, N., 2005: Wage Inequality and the Role of Multinationals: Evidence from UK Panel Data. Labour Economics 12(2), 223-249. Available at: https://ideas.repec.org/a/eee/labeco/v12y2005i2p223-249.html https://doi.org/10.1016/j.labeco.2003.11.003 
TAUSCH, A. - HESHMATI, A., 2012: The Effects of Multinational Corporation (MNC) Penetration on the Global Political Economy. A Re-Analysis of a Recurrent Sociological Proposition with Contemporary Data. Sociológia 44 (3): 314-347.

UNCTAD, 2016: Statistical Tables on the Least Developed Countries. Available at: https://unctad.org/en/PublicationsLibrary/ldc2016_Stats_en.pdf

UNCTAD, 2018a: Country classification. Available at: http://unctadstat.unctad.org/EN/Classifications/DimCountries_DevelopmentStatus_ Hierarchy.pdf

UNCTAD, 2018b: Methodology: Standard Country or Area Codes for Statistical Use (M49). Available at https://unstats.un.org/unsd/methodology/m49/

UNCTAD, 2018c: Classification of Economies. Handbook of statistics. Available at: https://stats.unctad.org/handbook/Annexes/Classifications.html\#ref_Unctad_2018a

UNCTAD, 2019a: Definitions and Sources. World Investment Report 2007: Transnational Corporation, Extractive Industries and Development, pp. 245-249. Available at https://unctad.org/en/Docs/wir2007p4_en.pdf

UNCTAD, 2019b: Methodological Note. World Investment Report 2016: Investor Nationality: Policy Challenges, pp. 1-80. Available at: https://unctad.org/en/PublicationChapters/wir2016chMethodNote_en.pdf

UNCTAD, 2019c: Foreign direct investment. Available at: https://unctadstat.unctad.org/wds/ReportFolders/reportFolders.aspx

UNCTAD, 2020: Country profiles. Retrieved from https://unctadstat.unctad.org/CountryProfile/GeneralProfile/en-GB/004/index.html

VOROBYOV, A. - ZHUKOV, S., 2000: Russia: Globalization, Structural Shifts and Inequality. CEPA Working Paper No. 19. https://doi.org/10.1093/acprof:oso/9780195145465.003.0008

VUKSIC, G., 2016: Effects of Private Ownership, Trade, and Foreign Direct Investment on Labor Productivity Growth in Transition Economies: Evidence from the Croatian Manufacturing Industry. Emerging Markets Finance and Trade, 52, 322-335. https://doi.org/10.1080/1540496X.2015.1011540

WORLD BANK, 2019a: Employment to Population Ratio. Available at: https://data.worldbank.org/indicator/SL.EMP.TOTL.SP.ZS

WORLD BANK, 2019b: Wage and salaried workers. Available at: https://data.worldbank.org/indicator/SL.EMP.WORK.ZS

WORLD BANK, 2019c: Gini index. Available at: https://data.worldbank.org/indicator/SI.POV.GINI

XU, B., 2000: Multinational Enterprises, Technology Diffusion, and Host Country Productivity Growth. Journal of Development Economics 62: 477-493. https://doi.org/10.1016/S0304-3878(00)00093-6

ZDRAVKOVIC, A. - MARTINOVIC, B. A., 2016: To which Extent did the FDI Contribute to Employment Growth in Transition Countries? Paper presented at the International Scientific Conference: Impact of Economic Policies on Attaining Resilient Growth, October 27th, Belgrade. https://www.ien.bg.ac.rs/ies-conference/ archive 16. html

ZUGIC, J., 2010: Foreign Direct Investment and Montenegrin Economy. Montenegrin Journal of Economics 6(11): 131-138. 


\section{Annex 1}

List of Transition Economies:

\begin{tabular}{|l|}
\hline Albania \\
\hline Armenia \\
\hline Azerbaijan \\
\hline Belarus \\
\hline Bosnia and Herzegovina \\
\hline Georgia \\
\hline Kazakhstan \\
\hline Kyrgyzstan \\
\hline Montenegro \\
\hline Moldova \\
\hline Russian Federation \\
\hline Serbia \\
\hline Tajikistan \\
\hline TFYR of Macedonia \\
\hline Turkmenistan \\
\hline Ukraine \\
\hline Uzbekistan \\
\hline
\end{tabular}

Note: Countries that no longer exist have been excluded from the analysis (i.e. Serbia and Montenegro, the Socialist Federal Republic of Yugoslavia, and the Union of Soviet Socialist Republics). 